\title{
ALIH FUNGSI LAHAN PERTANIAN DI KABUPATEN BOLAANG MONGONDOW TIMUR
}

\author{
Vecky Manoppo \\ Benu Olfie L. S. \\ Agnes E. Loho
}

\begin{abstract}
This study aims to know and identify the cause of land conversion in East Bolaang Mongondow Regency. This research will be conducted for 3 months. The data in this research is secondary data. Secondary data is data obtained by related institutions such as BPS (Central Bureau of Statistics), sub-district office and village office. The method used is descriptive method. The results showed that the cause of the occurrence of agricultural land conversion in East Bolaang Mongondow Regency due to the increasing number of population and economic factors that encourage people willing to sell their plantation land to be a place of business and government policies for road construction. From the three factors of land conversion, most the prominent is the increasing of population. *jnkd*.
\end{abstract}

Keywords: conversion of agricultural land, East Bolaang Mongondow Regency.

\begin{abstract}
ABSTRAK
Penelitian ini bertujuan untuk mengetahui dan mengidentifikasi penyebab terjadinya alih fungsi lahan di Kabupaten Bolaang Mongondow Timur. Penelitian ini akan dilakukan selama 3 bulan. Data pada penelitian ini adalah data sekunder. Data sekunder adalah data yang diperoleh instansi terkait seperti BPS (Badan Pusat Statistik), kantor kecamatan dan kantor desa. Metode yang digunakan secara deskriptif. Hasil penelitian menunjukkan bahwa penyebab terjadinya Alih Fungsi Lahan Pertanian di Kabutapen Bolaang Mongondow Timur karena bertambahnya jumlah penduduk dan faktor ekonomi yang mendorong masyarakat rela menjual lahan perkebunannya untuk dijadikan tempat usaha dan kebijakan pemerintah untuk pembuatan jalan, dari ketiga faktor terjadinya alih fungsi lahan yang paling menunjukan yaitu bertambah jumlah penduduk. *jnkd*.
\end{abstract}

Kata kunci: alih fungsi lahan pertanian, Kabupaten Bolaang Mongondow Timur.

\section{PENDAHULUAN}

\section{Latar Belakang}

Dalam pengembangan ekonomi suatu daerah, pertumbuhan penduduk dan pembangunan kota telah membuat perubahan fungsi lahan yang semula berfungsi sebagai media untuk bercocok tanam dalam pertanian berubah menjadi multifungsi pemanfaatan. Berubahnya pemanfaatan lahan tersebut disebut juga alih fungsi lahan. Alih fungsi lahan pertanian ke non pertanian yang tidak terkendali apabila tidak ditanggulangi dapat mendatangkan permasalahan yang serius, antara lain dapat mengancam kapasitas penyediaan pangan (iqbal dan Sumaryanto, 2007).

Luas sawah di Indonesia 8.183.886 Ha sedangkan laju konversi sawah di Indonesia $110.000 \mathrm{Ha} / \mathrm{th}$ (Suswono, 2012). Banyak lahan pertanian yang berubah fungsi menjadi 
bangunan - bangunan fisik seperti jalan, hotel, pabrik dan lain - lain. Selain itu jumlah penduduk yang terjadi juga mengakibatkan banyak lahan pertanian yang berubah fungsi menjadi pemukiman, baik itu yang di kembangkan oleh investor maupun perumahan sendiri.

Sulawesi Utara di perkirakan terancam kehilangan seluruh lahan pertanian dalam waktu kurun 20 tahun mendatang jika tidak ada komitmen dari seluruh pemerintah Kabupaten/Kota untuk membatasi terjadinya alih fungsi lahan pertanian. Luas lahan pertanian di Sulawesi Utara tiap tahun menyusut karena maraknya pembangunan kawasan pemukiman. Menurut kepala Dinas Pertanian dan peternakan Sulawesi Utara laju alih fungsi lahan pertanian di Sulut berjalan cukup cepat khususnya di Bolmong dan Minahasa (Jurnal Manado, Oktober Tahun 2012). Dengan pertumbuhan ekonomi yang semakin meningkat ini menuntut adanya pembangunan berbagai infrastruktur sehingga permintaan lahan yang ada menjadi cukup besar. Akibatnya banyak lahan pertanian yang beralih fungsi untuk memenuhi kebutuhan tersebut. Selain itu terjadinya alih fungsi lahan juga mungkin dikarenakan kurangnya insentif atau perhatian sektor pertanian ini oleh pemerintah, sehingga masyarakat beralih ke sektor lainya seperti sektor industri maupun perdagangan.

Kabupaten Bolaang Mongondow Timur merupakan salah satu Kabupaten hasil pemekaran dari Kabupaten Bolaang Mongondow. Secara administratif terdiri dari atas 5 kecamatan dan 81 desa dengan luas wilayah $878,31 \mathrm{~km}^{2}$. Dengan tinggi wilayah antara 1-900 diatas permukaan laut'. Sebagai daerah yang terletak didaerah kathulistiwa maka Kabupaten Bolaang Mongondow Timur hanya mengenal 2 musim, yaitu musim kemarau dan musim hujan. Jika dilihat dari potensi wilayah Kabupaten Bolaang Mongondow Timur merupakan wilayah pengembangan pertanian, dikarenakan sebagian besar wilayah merupakan lahan pertanian, perkebunan dan kehutanan, lahan sawah meliputi sawah setengah teknis, irigasi desa/ sederhana dan sawah tada. Hujan cukup deras didaerah ini. Begitu pula dengan lahan tegalan/ladang, perkebunan serta kehutanan yang sangat luas dan sangat potensial untuk dikembangkan dalam rangka meningkatkan pendapatan dan kesejahteraan masyarakat petani. Akan tetapi terjadi penurunan luas lahan pertanian pada Kabupaten Bolaang Mongondow Timur pada 7 tahun terakhir ini, Hal ini dapat dilihat pada Tabel 1.

Tabel 1. Luas Lahan Pertanian Kabupaten Bolaang Mongondow Timur (Ha)

\begin{tabular}{cccc}
\hline Tahun & $\begin{array}{c}\text { Luas Lahan } \\
\text { Pertanian }\end{array}$ & $\begin{array}{c}\text { Lahan } \\
\text { yang dialih } \\
\text { fungsi }\end{array}$ & $\begin{array}{c}\text { Perluasan } \\
\text { Lahan }\end{array}$ \\
\hline 2008 & 91,081 & - & - \\
2009 & 90,424 & 657 & - \\
2010 & 90,424 & - & - \\
2011 & 90,424 & - & - \\
2012 & 87,474 & 2,950 & - \\
2013 & 87,474 & - & - \\
2014 & 90,474 & - & 1,747 \\
\hline
\end{tabular}

Sumber: BPS, SULUT dalam angka dari tahun 2008 2014

Terjadinya penurunan luas lahan pertanian di Kabupaten Bolaang Mongondow Timur dari tahun ke tahun sementara sektor pertanian berperan penting dalam memberi kontribusi pada PDRB suatu daerah. Sektor pertanian menjadi penyedia bahan baku dari sumber daya alam yang ada dan kemudian bisa di olah menjadi suatu produk yang mempunyai nilai jual pada sektor industri pengolahan. Namun lahan pertanian yang semula berfungsi sebagai sektor pertanian berubah fungsi menjadi lahan non pertanian, seperti perumahan, kawasan industri, kawasan perdagangan dan sarana publik yang akan menimbulkan dampak secara ekonomi, sosial dan lingkungan.

Kabupaten Bolaang Mongondow Timur memiliki 81 desa dari 5 kecamatan, akan tetapi hanya ada beberapa desa yang mengalami terjadinya alih fungsi lahan pertanian ke non pertanian.

Dengan pertumbuhan ekonomi yang semakin meningkat yang terjadi di Kabupaten Bolaang Mongondow Timur ini menuntut adanya pembangunan berbagai infrastruktur sehingga permintaan akan lahan pertanian yang ada menjadi lebih besar. Akibatnya banyak lahan pertanian yang beralih fungsi untuk memenuhi kebutuhan tersebut. Alih fungsi 
lahan pertanian ke non pertanian senantiasa terjadi dalam pemenuhan aktivitas sosial ekonomi yang menyertai pertumbuhan penduduk kota. Persediaan lahan yang tetap sedangkan permintaannya yang terus bertambah menjadikan penggunaan lahan suatu kota berubah ke arah aktivitas yang lebih menguntungkan dilihat dari potensi sekitarnya yang ada.

\section{Rumusan Masalah}

Berdasarkan latar belakang permasalahan yang dikemukan di atas maka masalah utama dalam penelitian ini adalah bagaimana sehingga terjadinya alih fungsi lahan pertanian dan apa yang menyebabkan terjadinya alih fungsi lahan pertanian di Kabupaten Boalaang Mongondow Timur. Oleh sebab itu penelitian perlu dilakukan untuk mengetahui penyebab terjadinya alih fungsi lahan pertanian ke non pertanian.

\section{Tujuan Penelitian}

Tujuan yang ingin dicapai dalam penelitian ini adalah untuk mengetahui dan mengidentifikasi penyebab terjadinya alih fungsi lahan di Kabupaten Bolaang Mongondow Timur.

\section{Manfaat Penelitian}

1. Manfaat dari penelitian ini adalah sebagai tambahan ilmu bagi penelitian tentang faktor yang mempengaruhi alih fungsi lahan.

2. Sebagai bahan informasi berapa besar lahan pertanian yang berkurang karena pembangunan yang terjadi di Kabupaten Bolaang Mongondow Timur.

3. Sebagai bahan refrensi untuk penelitianpenelitian yang akan datang.

\section{METODE PENELITIAN}

\section{Waktu dan Tempat Penelitian}

Penelitian ini di laksanakan di Kabupaten Bolaang Mongondow Timur, dimana telah terjadi alih fungsi lahan pertanian ke non pertanian. Penelitian ini dilakukan selama 3 bulan.

\section{Metode Pengumpulan Data}

Data pada penelitian ini adalah data sekunder. Data sekunder adalah data yang diperoleh instansi terkait seperti BPS (Badan Pusat Statistik), kantor kecamatan dan kantor desa. Data sekunder misalnya berisi mengenai jumlah penduduk, serta jumlah industri di Kabupaten Bolaang Mongondow Timur dengan data time series.

\section{Metode Analisis Data}

Metode yang digunakan secara deskriptif yang mana hanya menguraikan penyebab terjadinya alih fungsi lahan pertanian di Kabupaten Bolaang Mongondow Timur.

\section{HASIL DAN PEMBAHASAN}

\section{Deskripsi daerah penelitian}

Kabupaten Bolaang Mongondow Timur adalah salah satu Kabupaten di Provinsi Sulawesi Utara. Letak geografis Kabupaten Bolaang Mongondow Timur di antara 0: 23' 25" LU - 124: 19' 39" BT dan 0: 57' 33" LU 124: 45' 38" BT. Yang secara administratif terletak di sebelah Barat Kota Kotamobagu, Bolaang Mongondow dan Kabupaten Bolaang Mongondow Timur. Luas wilayah Kabupaten Bolaang Mongondow Timur adalah \pm 910,176 $\mathrm{km}^{2}$ atau sekitar $5,95 \%$ dari luas wilayah Sulawesi Utara. Dengan batas wilayah sebagai berikut :

1. Sebelah Barat : Kabupaten Minahasa Selatan dan Kabupaten Bolaang Mongondow

2. Sebelah Timur : Laut Maluku

3. Sebelah Selatan : Kota Kotamobagu dan Kabupaten Bolaang Mongondow Selatan

4. Sebelah Utara : Kabupaten Minahasa Tengara dan Laut Maluku

Ibukota Kabupaten Bolaang Mongondow Timur adalah Tutuyan. Dengan panjang garis pantai $\pm 122,878 \mathrm{~km}$ dengan karekteristik sebagian besar adalah pantai berpasir membentang dari teluk Buyat hingga teluk Jiko Belanga dan Pulau Lampu. Panjang pantai tiap kecamatan menurut pengukuran citra satelit (2012) yaitu : Kecamatan Kotabunan $\pm 25,51$ 
$\mathrm{km}$, Kecamatan Tutuyan $\pm 27,016 \mathrm{~km}$, Kecamatan Nuangan $\pm 70,35 \mathrm{~km}$. Jadi luas wilayah laut 4 mil : 466,02 $\mathrm{km}^{2}$. Jadi daerah Kabupaten Bolaang Mongondow Timur terletak di daerah pesisir pantai laut Maluku. Daerah Kabupaten Bolaang Mongondow Timur mempunyai 5 Kecamatan yaitu Kecamatan Kotabunan, Kecamatan Tutuyan, Kecamatan Nuangan, Kecamatan Modayag Induk, dan Kecamatan Modayag Barat.

Kabupaten Bolaang Mongondow Timur merupakan salah satu Kabupaten hasil pemekaran dari Kabupaten Bolaang Mongondow. Secara administratif terdiri dari atas 5 Kecamatan dan 81 desa dengan luas wilayah $878,31 \mathrm{~km}^{2}$. Tinggi wilayah terletak pada 1 sampai dengan 900 diatas permukaan laut, dan terletak didaerah kathulistiwa sehingga hanya mengenal 2 musim, yaitu musim kemarau dan musim hujan. Jika dilihat dari potensi wilayah, maka Bolaang Mongondow Timur merupakan wilayah pengembangan pertanian, dikarenakan sebagian besar wilayah merupakan lahan pertanian, perkebunan dan kehutanan, lahan sawah meliputi sawah baik setengah teknis, irigasi desa/ sederhana dan sawah tadah hujan. Begitu pula dengan lahan tegalan/lading, perkebunan serta kehutanan yang sangat luas dan sangat potensial untuk dikembangkan dalam rangka meningkatkan pendapatan dan kesejahteraan masyarakat petani. Tabel 2 menunjukkan perkembangan luas lahan di Kabupaten Bolaang Mongondow Timur pada 7 tahun terakhir ini.

Tabel 2. Luas Lahan Pertanian Kabupaten Bolaang

\begin{tabular}{cccc}
\multicolumn{4}{c}{ Mongondow Timur (Ha) } \\
\hline Tahun & $\begin{array}{c}\text { Luas Lahan } \\
\text { Pertanian } \\
(\mathrm{Ha})\end{array}$ & $\begin{array}{c}\text { Lahan yang } \\
\text { beralih fungsi } \\
(\mathrm{Ha})\end{array}$ & $\begin{array}{c}\text { Perluasan } \\
\text { Lahan } \\
(\mathrm{Ha})\end{array}$ \\
\hline 2008 & 91,081 & - & - \\
2009 & 90,424 & 657 & - \\
2010 & 90,424 & - & - \\
2011 & 90,424 & - & - \\
2012 & 87,474 & 2,950 & - \\
2013 & 87,474 & - & - \\
2014 & 90,474 & - & 1,747 \\
\hline
\end{tabular}

Sumber: BPS, SULUT dalam angka dari tahun 2008 2014

Tabel 2 menunjukkan bahwa luas lahan pertanian di Kabupaten Bolaang Mongondow
Timur yang beralih fungsi dari lahan pertanian ke non pertanian pada tahun 2009 sampai 2012 sekitar 2,950 (Ha), tetapi mengalami kenaikan luas lahan atau bertambahnya luas lahan pertanian pada tahun 2014 sekitar 1,747 (Ha).

\section{Jumlah Penduduk}

\section{Kabupaten Bolaang Mongondow Timur}

Perkembangan jumlah penduduk setiap tahunnya bertambah. Jumlah kelahiran yang cukup tinggi merupakan faktor penyebab bertambahnya jumlah penduduk. Dengan bertambahnya jumlah penduduk tiap tahun akan menyebabkan aktivitas penduduk juga meningkat yang membutuhkan lahan untuk pemukiman sementara lahan terbatas. Di Kabupaten Bolaang Mongondow Timur kenaikan jumlah penduduk paling tinggi terjadi pada tahun 2009 ke 2010 sebesar 6,68\%. Hal ini menyimpulkan jumlah penduduk di Kabupaten Bolaang Mongondow Timur dari tahun ke tahun terus meningkat, dan kebutuhan akan lahan pertanian terus bertambah.

Tabel 3. Jumlah Penduduk Kabupaten Bolaang Mongondow Timur Tahun 2008 sampai Tahun 2014

\begin{tabular}{ccc}
\hline Tahun & $\begin{array}{c}\text { Jumlah Penduduk } \\
\text { Kabupaten Bolaang } \\
\text { Mongondow Timur }\end{array}$ & $\begin{array}{c}\text { Presentase } \\
\text { Peningkatan Jumlah } \\
\text { Penduduk (\%) }\end{array}$ \\
\hline 2008 & 58.656 & - \\
2009 & 59.401 & 1,25 \\
2010 & 63.654 & 6,68 \\
2011 & 64.370 & 1,11 \\
2012 & 65.511 & 1,74 \\
2013 & 66.677 & 1,74 \\
2014 & 67.824 & 1,69 \\
\hline
\end{tabular}

Sumber: BPS, Bolaang Mongondow Timur Dalam Angka 2015

\section{Jumlah Industri}

di Kabupaten Bolaang Mongondow Timur

Terjadi Peningkatan jumlah usaha kecil, usaha menengah dan usaha besar di Kabupaten Bolaang Mongondow Timur pada Tahun 2008 hinga Tahun 2010 yang dari 317 unit menjadi 492 unit. Kemudian mengalami peningkatan cukup besar pada tahun 2011, kenaikan mencapai 44,97\% yaitu 894 unit. Kemudian pada tahun 2013 peningkatan jumlah usaha meningkat cukup besar yaitu 1.931 unit, kenaikan sebesar 47,02 \%. Hal ini dapat di simpulkan pengaruh terus bertambahnya jumlah 
industri di Kabupaten Bolaang Mongondow Timur telah mengakibatkan penurunan Luas lahan pertanian.

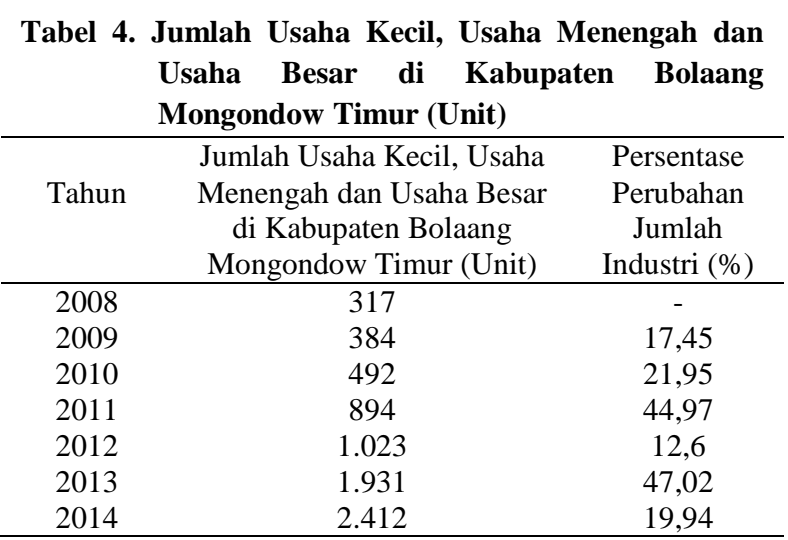

Sumber: BPS SULUT, Bolaang Mongondow Timur Dalam Angka 2015

Tingginya Penambahan jumlah usaha kecil, usaha menengah, dan usaha besar pada Kabupaten Bolaang Mongondow Timur terlihat pada Tahun 2012, 2013 dan 2014 yang mencapai 1.023 unit menjadi 1.931 unit hingga 2.412 unit.

\section{Penyebab Terjadinya Alih Fungsi Lahan di Kabupaten Bolaang Mongondow Timur}

Kabupaten Bolaang Mangondow Timur terdiri dari 5 Kecamatan dan daerah yang mengalami alih fungsi lahan ada 4 Kecamatan yaitu Kecamatan Kotabunan, Kecamatan Tutuyan, Kecamatan Nuangan dan Kecamatan Modayag. Terjadinya alih fungsi lahan di Kabupaten Bolaang Mongondow Timur disebabkan oleh pemerintah dan masyarakat. Alih fungsi lahan yang disebabkan pemerintah yaitu adanya kebijakan untuk meningkatkan pembangunan seperti infrastruktur jalan, fasilitas umum seperti sekolah, masjid dan lain-lain. Sedangkan alih fungsi yang disebabkan oleh masyarakat yaitu bertambahnya penduduk setiap tahunnya, sehingga kebutuhan akan lahan untuk pembangunan tempat tinggal semakin bertambah. Selain itu masyarakat khususnya petani rela menjual lahan perkebunannya untuk memenuhi kebutuhan ekonomi mereka karena nilai jual atau jumlah produksi yang di dapat dari hasil pertanian tidak mampu untuk mencukupi kebutuhan ekonomi keluarga. Adapun juga karena masuknya perusahan - perusahan, baik dari luar daerah dan dalam daerah untuk berinvestasi di daerah Kabupaten Bolaang Mongondow Timur.

\section{Kecamatan Kotabunan}

Kecamatan Kotabunan terdiri dari 5 desa yaitu Kotabunan, Bukaka, Buyat, Bulawan dan Paret. Setiap desa terdapat alih fungsi lahan pertanian ke non pertanian seperti yang dijelaskan pada Tabel 5.

\begin{tabular}{|c|c|c|c|c|c|}
\hline No. & Kecamatan & Desa & $\begin{array}{c}\text { Lahan } \\
\text { Pertanian }\end{array}$ & Ahli Fungsi & Ket. Data \\
\hline 1 & 2 & 3 & 4 & 5 & 6 \\
\hline \multirow{20}{*}{1.} & \multirow{20}{*}{ Kotabunan } & \multirow{5}{*}{ 1. Buyat } & \multirow{5}{*}{ Kelapa } & Pemukiman & Ada \\
\hline & & & & Penduduk & \\
\hline & & & & Sekolah & Ada \\
\hline & & & & Jalan & Ada \\
\hline & & & & Café & Ada \\
\hline & & \multirow{5}{*}{ 2. Bukaka } & \multirow{5}{*}{$\begin{array}{l}\text { Kelapa dan } \\
\text { Cengkeh }\end{array}$} & Pemukiman & Ada \\
\hline & & & & Penduduk & \\
\hline & & & & Jalan & Ada \\
\hline & & & & Sekolah & Tidak Ada \\
\hline & & & & Tempat Usaha & Tidak Ada \\
\hline & & \multirow{3}{*}{ 3. Bulawan } & \multirow{3}{*}{ Kelapa } & Pemukiman & Ada \\
\hline & & & & Penduduk & \\
\hline & & & & Jalan & Ada \\
\hline & & \multirow{4}{*}{ 4. Kotabunan } & Kelapa, Cengkih & $\begin{array}{l}\text { Tambang } \\
\text { Rakyat }\end{array}$ & Ada \\
\hline & & & dan Lahan & Pemukiman & Ada \\
\hline & & & Perkebunan & Penduduk & \\
\hline & & & Lainnya & Jalan & Ada \\
\hline & & \multirow{3}{*}{ 5. Paret } & Kelapa dan & Pemukiman & Ada \\
\hline & & & Lahan & Penduduk & \\
\hline & & & $\begin{array}{l}\text { Perkebunan } \\
\text { lainnya }\end{array}$ & Jalan & Ada \\
\hline
\end{tabular}

Tabel 5 menunjukkan beberapa alih fungsi lahan pertanian yang terjadi di Kecamatan Kotabunan.

a. Alih Fungsi Lahan di Desa Buyat

Desa Buyat merupakan salah satu desa yang ada di Kecamatan Kotabunan dengan batas wilayah sebelah barat berbatasan dengan desa Ratatotok, Minahasa Tenggara, sebelah utara berbatasan dengan Kabupaten Minahasa Selatan, kemudian sebelah selatan berbatasan dengan desa Bulawan. Masyarakat desa Buyat sebagian besar bermata pencaharian sebagai petani/pekebun dengan hasil unggulan seperti kelapa, cengkih, coklat, jagung, singkong, pala dan kopi.

Terjadinya alih fungsi lahan pertanian di desa Buyat disebabkan karena kebutuhan ekonomi masyarakat yang membuat masyarakat rela mengalih fungsikan lahan perkebunan 
kelapa menjadi sebuah pemukiman penduduk dan sebagian lahan juga dijadikan sekolah, jalan dan café.

b. Alih Fungsi Lahan di Desa Bukaka

Desa Bukaka merupakan salah satu desa yang ada di Kecamatan Kotabunan Kabupaten Bolaang Mongondow Timur. Terbentuknya desa Bukaka karena adanya transmigrasi dari desa Buyat, Bulawan dan Kotabunan. Secara geografis desa Bukaka berbatasan sebelah Utara dengan Tombatu, sebelah Timur dengan desa Buyat, sebelah Barat dengan Minahasa Selatan dan sebelah Selatan dengan desa Kotabunan.

Desa Bukaka sendiri memiliki potensi unggulan dalam bidang perkebunan seperti kakao, pala, cengkeh, kelapa dan jagung. Tetapi untuk mempermudah akses kendaraan bermotor masuk ke desa Bukaka, sehingga lahan perkebunan kelapa dan perkebunan cengkeh telah dialih fungsikan dan di bangun infrastruktur jalan. Kemudian berkurangnya lahan pertanian di desa Bukaka karena adanya kebijakan pemerintah untuk pembangunan sekolah dan kantor desa serta perluasan desa akibat bertambahnya penduduk di desa Bukaka.

c. Alih Fungsi Lahan di Desa Bulawan

Desa Bulawan merupakan salah satu desa yang ada di Kecamatan Kotabunan dengan batas wilayah sebelah Utara berbatasan dengan desa Buyat, sebelah Timur berbatasan dengan laut Maluku, sebelah Selatan berbatasan dengan desa Kotabunan, sebelah Barat berbatasan dengan desa Bukaka.

Mata pencaharian masyarakat desa Bulawan sendiri sebagai petani, nelayan dan penambang dengan sumber daya alam yang diantaranya yaitu kelapa, cengkeh, emas, dan perikanan. Tetapi karena bertambahnya penduduk desa Bulawan sehingga petani menjual lahan kelapa untuk membangun tempat tinggal. Kemudian untuk mempermudah akses kendaraan bermotor masuk ke desa Bulawan sehingga lahan perkebunan kelapa di alih fungsikan menjadi infrastruktur jalan.

d. Alih Fungsi Lahan di Desa Kotabunan

Desa Kotabunan merupakan Ibu Kota Kecamatan Kotabunan yang ada di Kabupaten Bolaang Mongondow Timur. Kecamatan Kotabunan adalah Kecamatan tertua di pesisir Timur Kabupaten Bolaang Mongondow Timur.
Mata pencaharian desa Kotabunan sendiri yaitu tambang emas, kelautan perikanan dan perikanan. Bertambahnya luas tambang rakyat, serta dibangunnya perusahan tambang menjadikan lahan perkebunan kelapa, cengkeh dan lahan pertanian lainnya berkurang. Hal itu disebabkan karena pemilik lahan pertanian rela menjual lahan pertaniannya karena selain kebutuhan ekonomi di lain pihak membuka lapangan kerja baru dan menambah penghasilan. Kemudian adanya kebijakan pemerintah untuk menambah akses jalan baru, masyarakat Kotabunan rela menghibahkan lahan pertaniannya untuk untuk membangun tempat tinggal karena bertambahnya jumlah penduduk.

e. Alih Fungsi Lahan di Desa Paret

Desa Paret merupakan desa yang ada di Kecamatan Bolaang Mongondow Timur, dengan batas wilayah sebelah Utara dengan desa Kotabunan, sebelah Selatan dengan Kayumoyondi, sebelah Timur dengan laut Maluku, dan sebelah Barat dengan Minahasa Selatan. dengan luas wilayah $\pm 4000 \mathrm{Ha}$.

Mata pencaharian masyarakat desa yaitu dalam bidang pertanian dan perkebunan dengan sumber daya alam yang dimiliki seperti kelapa, cengkeh, pala, jagung dan kopi.

Dengan bertambahnya penduduk desa Paret sehingga petani kelapa rela menjual dan mengalih fungsikan lahannya untuk membangun sebuah tempat tinggal. Kemudian bertambahnya infrastruktur jalan yang masuk di lahan perkebunan kelapa agar mempermudah akses kendaraan bermotor.

Tabel 6. Jumlah Alih Fungsi Yang Terjadi di Kecamatan Kotabunan

\begin{tabular}{clcc}
\hline No & Alih Fungsi & Jumlah & Hektar \\
\hline 1 & Jalan & 5 & 43,32 \\
2 & Pemukiman & 4 & 72,49 \\
3 & Tambang & 1 & 12,36 \\
4 & Tempat Usaha & 1 & - \\
5 & Sekolah & 1 & - \\
\hline Jumlah & & 12 & - \\
\hline
\end{tabular}

Sumber: Data yang Diolah dari Data Primer

Tabel 6 Menunjukkan jumlah alih fungsi yang terjadi di Kecamatan Kotabunan, berdasarkan tabel 4 di ketahui jumlah lahan pertanian yang di alih fungsikan ke pembangunan dengan jumlah 12, di tabel 
tersebut menunjukkan pembangunan infrastruktur jalan cenderung lebih banyak dari pada lainnya.

\section{Kecamatan Tutuyan}

Kecamatan Tutuyan terdiri dari 7 desa yaitu Kayumoyondi, Tombolikat, Tutuyan, Tutuyan II, Togid, Dodap dan Dodap Pantai. Akan tetapi hanya ada 6 desa yang mengalami alih fungsi lahan pertanian ke non pertanian seperti yang dijelaskan pada Tabel 7.

\begin{tabular}{|c|c|c|c|c|c|}
\hline No. & Kecamatan & Desa & $\begin{array}{c}\text { Lahan } \\
\text { Pertanian }\end{array}$ & Ahli Fungsi & Ket. Data \\
\hline 1 & 2 & 3 & 4 & 5 & 6 \\
\hline \multirow[t]{15}{*}{1} & Tutuyan & 1. Kayumoyondi & Kelapa & $\begin{array}{l}\text { Pemukiman } \\
\text { Penduduk }\end{array}$ & Ada \\
\hline & & & & hotel & Tidak ada \\
\hline & & & & Jalan & Ada \\
\hline & & 2. Tombolikat & $\begin{array}{l}\text { Kelapa dan } \\
\text { Cengkeh }\end{array}$ & $\begin{array}{l}\text { Pemukiman } \\
\text { Penduduk }\end{array}$ & Ada \\
\hline & & & & Jalan & Ada \\
\hline & & 3. Tutuyan & $\begin{array}{l}\text { Kelapa dan } \\
\text { Cengkeh }\end{array}$ & $\begin{array}{l}\text { Pemukiman } \\
\text { Penduduk }\end{array}$ & Ada \\
\hline & & & & Perkantoran & Ada \\
\hline & & & & Jalan & Ada \\
\hline & & 4. Tutuyan II & $\begin{array}{l}\text { Kelapa, } \\
\text { Cengkih }\end{array}$ & Perkantoran & Ada \\
\hline & & & $\begin{array}{l}\text { danLahan } \\
\text { Perkebunan }\end{array}$ & $\begin{array}{l}\text { Pemukiman } \\
\text { Penduduk }\end{array}$ & Ada \\
\hline & & & Lainnya & Jalan & Ada \\
\hline & & 5. Togid & $\begin{array}{l}\text { Kelapa dan } \\
\text { Lahan }\end{array}$ & $\begin{array}{l}\text { Pemukiman } \\
\text { Penduduk }\end{array}$ & Ada \\
\hline & & & $\begin{array}{l}\text { Perkebunan } \\
\text { lainnya }\end{array}$ & Jalan & Ada \\
\hline & & 6. Dodap & $\begin{array}{l}\text { Kelapa, } \\
\text { Cengkih }\end{array}$ & $\begin{array}{l}\text { Pemukiman } \\
\text { Penduduk }\end{array}$ & Tidak ada \\
\hline & & & $\begin{array}{l}\text { danLahan } \\
\text { Perkebunan }\end{array}$ & Jalan & Ada \\
\hline
\end{tabular}

Tabel 7 menunjukkan bahwa di kecamatan Tutuyan memiliki alih fungsi lahan yang sama.

\section{a. Alih Fungsi Lahan di Desa Kayumoyondi}

Desa Kayumoyondi merupakan desa yang terletak di Kecamatan Tutuyan sekaligus desa yang berbatasan dengan desa paret yang terletak di Kecamatan Kotabunan, dengan batas wilayah sebelah timur laut maluku, sebelah barat dengan kawasan hutan, sebelah utara dengan kecamatan kotabunan, dan sebelah selatan dengan desa kotabunan. Mata pencaharian desa kayumoyondi yaitu di bidang pertanian, perkebunan, dan pegawai negeri, dengan sumber daya alam yaitu kelapa, cengkeh, dan jagung.

Terjadinya alih fungsi lahan di Desa Kayumoyondi karena lahan perkebunan kelapa di alih fungsikan menjadi pemukiman penduduk akibat bertambahnya jumlah penduduk dan migrasi serta pembangunan hotel. Kemudian untuk mempermudah akses jalan di Desa Kayumoyondi sehingga sebagian lahan dialih fungsikan untuk pembuatan infrastuktur jalan.

b. Alih Fungsi Lahan di Desa Tombolikat

Desa Tombolikat merupakan desa yang terletak di Kecamatan Tutuyan, dengan batas wilayah sebelah timur dengan laut maluku, sebelah barat dengan kawasan hutan, sebelah utara dengan desa kayumoyondi dan sebelah selatan dengan tombolikat selatan. Mata pencaharian masyarakat desa tombolikat yaitu sebagai petani dan pegawai negeri sipil. Sumber daya alam yaitu cengkeh, kelapa, kakao dan jagung.

Beralihnya lahan pertanian di Desa Tombolikat karena telah di bangun jalan dan bertambanya pemukiman penduduk, alasannya karena bertambanya jumlah penduduk dan migrasi, kemudian di alih fungsikan menjadi jalan karena adanya kebijakan pemerintah.

c. Alih Fungsi Lahan di Desa Tutuyan

Desa Tutuyan merupakan Ibukota Kecamatan Tutuyan, sekaligu Ibukota Kabupaten Bolaang Mongondow Timur, dengan batas wilayah sebelah Utara berbatasan dengan desa Tombolikat Selatan, sebelah Timur dengan laut Maluku, sebelah Barat dengan Minahasa Selatan dan sebelah Selatan berbatasan dengan desa Tutuyan II (dua).

Mata pencaharian masyarakat desa Tutuyan yaitu sebagai petani dan usaha-usaha dagang dengan sumber daya alam yang dimiliki berupa kebun cengkeh, kelapa dan jagung. Terjadinya alih fungsi lahan pertanian di Desa Tutuyan menjadi pemukiman penduduk dikarenakan adanya pertumbuhan penduduk baru dan migrasi. Kemudian di alih fungsikan menjadi jalan dan perkantoran karena adanya kebijakan dari pemerintah.

d. Alih Fungsi di Desa Tutuyan II (Dua)

Desa Tutuyan II (dua) merupakan pecahan dari desa Tutuyan yang berada di Kabupaten Bolaang Mongondow Timur dengan batas wilayah sebelah Barat berbatasan dengan Minahasa Selatan, sebelah Timur dengan Laut Maluku, sebelah Selatan dengan desa Togid, dan sebelah Utara dengan desa Tutuyan induk.

Adapun hasil-hasil pertanian masyarakat desa Tutuyan II (dua) berupa kelapa, cengkeh, 
pala, jagung, coklat dan hasil-hasil perkebunan lainnya. Tetapi karena adanya pertumbuhan penduduk baru dan migrasi sehingga lahan perkebunan di desa Tutuyan II (dua) banyak yang dialih fungsikan menjadi tempat tinggal masyarakat desa Tutuyan II (dua). Kemudian ada juga yang di alih fungsikan menjadi jalan dan perkantoran karena adanya kebijakan dari pemerintah.

e. Alih Fungsi Lahan di Desa Togid

Desa Togid merupakan desa yang terletak di Kecamatan Tutuyan, dengan batas wilayah sebelah timur dengan laut maluku, sebelah barat dengan kawasan perkebunan, sebelah utara dengan desa Tutuyan dan sebelah selatan dengan desa Dodap. Mata pencaharian masyarakat desa yaitu pegawai negeri dan petani, dan sumber daya alam yaitu kelapa, cengkeh, dan jagung.

Terjadinya alih fungsi lahan pertanian di Desa Togid karena bertambahnya pemukiman penduduk yang terletak di daerah perkebunan kelapa karena bertambahnya penduduk dan migrasi sehingga perlu perluasan lahan penduduk untuk pembangunan rumah penduduk. Serta pembangunan jalan atau akses usaha tani yang masuk di daerah pertanian.

f. Alih Fungsi di Desa Dodap

Desa Dodap merupakan desa yang terletak di Kecamatan Tutuyan dengan batas wilayah sebelah Timur berbatasan dengan Dodap Pantai, sebelah Barat dengan kawasan perkebunan desa Dodap, sebelah Utara dengan desa Togid dan sebelah Selatan dengan desa Motongkad. Mata pencaharian masyarakat desa Dodap ialah sebagai petani. Adapun sumber daya alam yang terdapat di miliki desa Dodap berupa kelapa, cengkeh dan pala.

Tanaman yang mendominasi di desa Dodap adalah kelapa dan cengkeh, terjadinya konversi lahan perkebunan di desa Dodap disebabkan oleh pembangunan infrastruktur jalan yang menghubungkan akses dari desa ke tempat wisata, masyarakat rela menghibahkan sebagian lahan perkebunannya karena mereka mendapat keuntungan atas adanya tempat wisata tersebut yaitu mereka dapat membuka usaha kecil yang berada ditempat wisata yang bernama Tanjung Woka alasan lainnya karena keuntungan dari hasil produksi pada perkebunan kelapa tidak cukup menunjang keperluan kehidupan sehari-hari. Bertambahnya jumlah penduduk sehingga sebagian lahan dialih fungsikan menjadi tempat tinggal.

Tabel 8. Jumlah Alih Fungsi Yang Terjadi di Kecamatan Tutuyan

\begin{tabular}{clcc}
\hline No & Alih Fungsi & Jumlah & Hektar \\
\hline 1 & Jalan & 6 & 43,5 \\
2 & Pemukiman & 6 & 81,3 \\
3 & Hotel & 1 & - \\
4 & Kantor & 1 & 14,9, \\
\hline Jumlah & & 14 & - \\
\hline
\end{tabular}

Sumber: Data yang diolah dari Data Primer

\section{Kecamatan Nuangan}

Nuangan merupakan salah satu desa sekaligus kecamatan yang berbeda di Kabupaten Bolaang Mangondow Timur. Kecamatan Nuangan terdiri dari beberapa desa yaitu desa Atoga, Molobog, Bai, Idumun, Iyok, Jiko, Jiko Belanga, Loyow, Matabulu, Motongkad dan Nuangan. Akan tetapi hanya ada beberapa desa yang di laporkan terjadi alih fungsi lahan pertanian ke non pertanian.

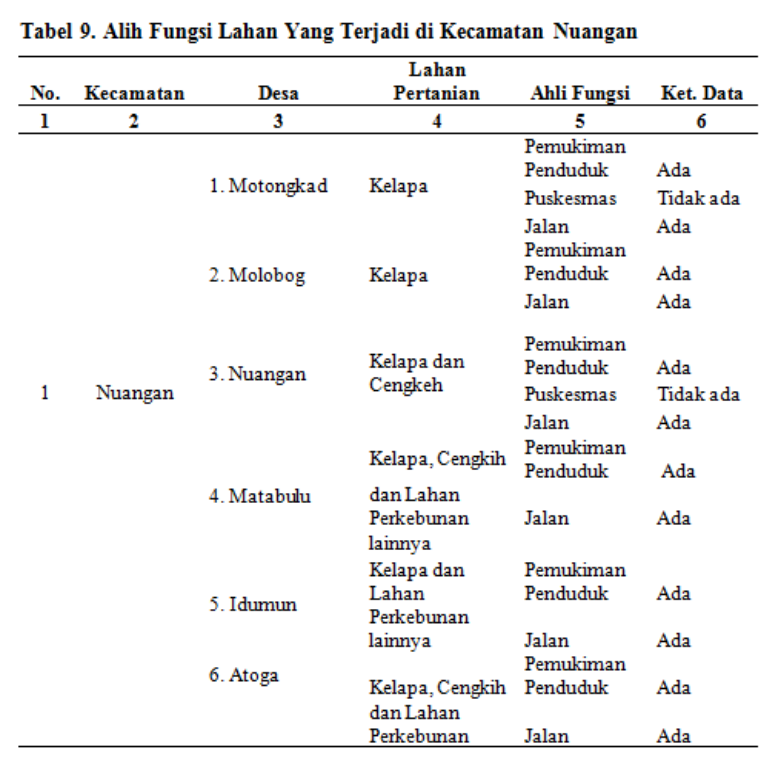

Tabel 9 menunjukkan bahwa di kecamatan Nuangan memiliki alih fungsi lahan.

a. Alih Fungsi Lahan di Desa Motongkad

Desa Motongkad merupakan desa yang terletak di Kecamatan Nuangan sekaligus desa berbatasan dengan Kecamatan Tutuyan yaitu desa Dodap. Desa Motongkad memliki batas 
wilayah yaitu sebelah Timur berbatasan dengan desa Motongkad II, sebelah Utara dengan Kecamatan Tutuyan, sebelah Barat dengan Minahasa Selatan dan sebelah Selatan dengan desa Atoga. Mata pencaharian masyarakat desa Motongkad yaitu Pegawai Negeri Sipil (PNS) dan petani, dengan sumber daya alam yaitu kelapa dan cengkeh.

Terjadinya alih fungsi lahan di desa Motongkad kareena lahan perkebunan kelapa yang berada dekat dengan pemukiman penduduk telah dilaporkan akan segera di bangun Puskesmas, selain itu ada pula pembuatan jalan perkebunan untuk akses usaha tani. Bertambahnya penduduk sangat mendorong terjadinya alih fungsi lahan perkebunan, dan yang jadi korban yaitu perkebunan kelapa yang berada dekat pemukiman rela dijual oleh petani kelapa karena hasil produksi dari perkebunan kelapa tidak cukup untuk memenuhi kebutuhan keluarga, sehingga petani dengan terpaksa menjual lahan perkebunannya.

b. Alih Fungsi Lahan di Desa Molobog

Desa Molobog merupakan desa yang terletak di Kecamatan Nuangan dengan batas wilayah sebelah Timur dengan desa Molobog Pantai, sebelah Utara dengan desa Atoga, sebelah Barat dengan perkebunan kelapa dan sebelah Selatan dengan desa Nuangan. Mata pencaharian masyarakat desa Molobog yaitu petani dan pekebun. Selain itu ada beberapa masyarakat yang berprofesi sebagai Pegawai Negeri Sipil (PNS) dan pengusaha. Sumber daya alam yang dimiliki desa Molobog yaitu perkebunan kelapa, cengkeh, pala, vanili dan jagung.

Terjadinya alih fungsi lahan pertanian ke non pertanian di desa Molobog karena bertambahnya penduduk setiap tahunnya, sehingga banyak perkebunan kelapa yang dialih fungsikan menjadi tempat tinggal. Selain itu bertambahnya luas jalan yang menghubungkan antara desa dan perkebunan penduduk yang dulunya luas jalan hanya dapat dimasuki dengan jalan kaki, tetapi dengan adanya kebijakan dari pemerintah desa dan daerah di buatlah jalan usaha tani yang sekarang bisa di lewati oleh kendaraan bermotor.

c. Alih Fungsi Lahan di Desa Nuangan
Desa Nuangan merupakan Ibu Kota Kecamatan Nuangan dengan batas wilayah sebelah Timur dengan desa Loyow dan Iyog, sebelah Selatan dengan Matabulu, sebelah Barat dengan desa Lanud dan sebelah Utara dengan desa Molobog. Mata pencaharian masyarakat desa Nuangan yaitu petani, Pegawai Negeri Sipil (PNS), pengusaha serta nelayan. Sumber daya alam yang ada yaitu perkebunan cengkeh, kelapa dan jagung.

Terjadinya alih fungsi lahan pertanian ke non pertanian di desa Nuangan karena semakin bertambahnya penduduk setiap tahun membuat perkebunan kelapa yang berada dekat dengan tempat tinggal di buat menjadi tempat tinggal penduduk serta pembangunan infrastruktur jalan dan fasilitas umum seperti Puskesmas.

d. Alih Fungsi Lahan di Desa Matabulu

Desa Matabulu merupakan desa yang terletak di Kecamatan Nuangan dengan batas wilayah sebelah Timur dengan laut Maluku, sebelah Barat dengan perkebunan cengkeh, sebelah Selatan dengan desa Jiko Belanga dan sebelah Utara dengan desa Nuangan. Mata pencaharian masyarakat desa Matabulu sebagian besar sebagai petani cengkeh dan kelapa karena mempunyai sumber daya alam dengan kelapa dan cengkeh yang cukup besar.

Terjadinya alih fungsi lahan pertanian ke non pertanian karena bertambahnya penduduk dan kebijakan pemerintah untuk pembuatan jalan batu untuk menghubungkan antara Jiko Belanga dan Matabulu dengan adanya pembuatan jalan tersebut memasuki area perkebunan kelapa dan cengkeh. Serta perkebunan kelapa yang berada di dekat pesisir pantai telah menjadi pemukiman penduduk.

e. Alih Fungsi Lahan di Desa Idumun

Desa idumun merupakan sala satu desa yang berada di Kecamatan Nuangan dengan batas wilayah sebelah Utara dengan desa Bai, sebelah Timur dengan Perkebunan Nuangan, sebelah Selatan dengan desa Nuangan dan sebelah Barat dengan Bolaang Mongondow Selatan. Mata pencaharian masyarakat desa Idumun yaitu petani dengan sumber daya alam berupa kelapa, cengkeh, pala dan jagung.

Terjadinya laih fungsi lahan pertanian ke non pertanian karena bertambahnya penduduk sehingga sebagian perkebunan dijadikan tempat

Agrisosioekonomi: 
tinggal dan dijadikan akses jalan untuk usaha tani.

f. Alih Fungsi Lahan di Desa Atoga

Desa Atoga merupakan salah satu desa yang berada di Kecamatan Nuangan dengan batas wilayah sebelah Barat berbatasan dengan desa Atoga Timur, sebelah Utara dengan desa Guaan, sebelah Timur dengan desa Motongkad, sebelah Selatan dengan desa Molobog. Mata pencaharian masyarakat desa Atoga yaitu sebagai petani karena di sekeliling desa Atoga terdapat lahan perkebunan cengkih yang subur.

Terjadinya alih fungsi lahan pertanian ke non pertanian karena bertambahnya penduduk sehingga sebagian lahan perkebunan cengkeh yang berada dekat dengan pemukiman penduduk telah di jadikan tempat tinggal. Selain itu dijadikan jalan untuk usaha tani.

\begin{tabular}{cccc} 
Tabel & $\begin{array}{c}\text { 10. } \\
\text { Jumlah } \\
\text { Terjadi } \\
\text { Nuangan }\end{array}$ & $\begin{array}{c}\text { Alih } \\
\text { di }\end{array}$ & $\begin{array}{c}\text { Fungsi } \\
\text { Kecamatan }\end{array}$ \\
\hline No & Alih Fungsi & Jumlah & Hektar \\
\hline 1 & Jalan & 6 & 26,7 \\
2 & Pemukiman & 6 & 12,5 \\
3 & Puskesmas & 2 & - \\
\hline Jumlah & & 14 & -
\end{tabular}

Sumber: Data yang diolah dari Data Primer

\section{Kecamatan Modayag}

Modayag merupakan salah satu desa sekaligus kecamatan yang berbeda di Kabupaten Bolaang Mangondow Timur. Kecamatan Modayag terdiri dari beberapa desa yaitu desa Badaro, Bongkudai Baru, Buyandi, Guaan, Kokapoi, Candi Rejo, Lanut, Liberia, Moat, Modayag, Modayag II dan III, Mokitompia, Mototompian, Purworejo, Purworejo Timur, Sumber Rejo, dan Tobongon. Adapun alih fungsi lahan pertanian di Kecamatan Modayag yaitu Pembuatan jalan Usaha Tani dan pembuatan jalan baru yang menghubungkan desa - desa yang ada di Kecamatan Modayag sebesar 39,6 Hektar. Alih fungsi ini adalah kebijakan dari pemerintah Kabupaten Bolaang Mongondow Timur bekerja sama dengan Dinas Pekerjaan Umum.

\section{KESIMPULAN DAN SARAN}

\section{Kesimpulan}

Penyebab terjadinya Alih Fungsi Lahan Pertanian di Kabutapen Bolaang Mongondow Timur karena bertambahnya jumlah penduduk dan faktor ekonomi yang mendorong masyarakat rela menjual lahan perkebunannya untuk dijadikan tempat usaha dan kebijakan pemerintah untuk pembuatan jalan, dari ketiga faktor terjadinya alih fungsi lahan yang paling menunjukan yaitu bertambah jumlah penduduk.

Pemerintah $\begin{gathered}\text { Saran } \\ \text { perlu untuk lebih }\end{gathered}$ memperketat ijin alih fungsi lahan dari lahan pertanian ke lahan non pertanian dan meninjau kembali kebijakan kebijakan untuk pembangunan yang mengorbankan lahan pertanian.

\section{DAFTAR PUSTAKA}

Iqbal, M dan Sumaryanto, 2007. Strategi Pengendalian Alih Fungsi Lahan Pertanian Bertumpu Pada Partisipasi Masyarakat. Pusat Analisis Sosial Ekonomi dan Kebijakan Pertanian, Volume 5 No. 2, Juni 2007. Bogor.

Suswono, 2012. Penyediaan Lahan Pangan. Kementrian Pertanian. Jakarta Food Security Summit. Jakarta. 